J. clin. Path., 1977, 30, 928-932

\title{
Pregnancy and antibody to factor VIII
}

\author{
JENNIFER VOKE AND ELIZABETH LETSKY
}

From the Haemophilia Centre, Royal Free Hospital, London NW3 and Queen Charlotte's Maternity Hospital, London W6, UK

SUMMARY A patient who had developed a factor VIII antibody three weeks after the birth of her first baby became pregnant for the second time 10 weeks later. The pregnancy was normal apart from extensive spontaneous bruising during the first two months. This bleeding tendency disappeared in the third month of gestation and the antibody became undetectable during the eighth month. It had not reappeared seven months later. An unexplained long bleeding time and low platelet count were noted during the last trimester. The literature on postpartum coagulation inhibitors is reviewed.

Factor VIII antibody is a rare cause of haemorrhage in previously healthy postpartum women. Women who may have had this type of haemorrhagic disorder were reported by Rosenthal et al.(1937) and by Madison and Quick (1945). The nature of the defect was first reported in 1946 when the plasma of two such patients was shown not only to resemble haemophilic plasma but to have an inhibitory effect on normal clotting (Fantl and Nance, 1946; Chargaff and West, 1946). Dreskin and Rosenthal (1950) and Frick (1953), studying similar postpartum inhibitors, demonstrated that they were directed against antihaemophilic factor. Shapiro (1967) and Robboy et al. (1970) showed that these inhibitors were immunoglobulins as are the factor VIII antibodies found in treated haemophiliacs (Leitner et al., 1963).

We describe a patient with a postpartum factor VIII inhibitor who became pregnant again at a time when her factor VIII level was extremely low and while haemorrhagic manifestations were still present.

\section{Case report}

A previously healthy 33-year-old Caucasian woman with no family history of abnormal bleeding developed spontaneous bruises 20 days after her first child was born. The pregnancy had been normal but Kielland forceps delivery was necessary for delay in the second stage and was followed by a selflimiting haemorrhage of approximately $500 \mathrm{ml}$. On the fifth day there was a further brisk haemorrhage, and retained products of conception were removed by curettage. Bleeding then ceased and blood transfusion was not necessary.

Received for publication 23 March 1977
Twenty days after delivery large spontaneous bruises began to appear on the arms and legs and similar bruises continued to develop for the next four months. Slight bleeding from the gums was noticed several times but there were no haemarthroses nor haemorrhages from any other site. The baby was completely normal and breast feeding continued for four months.

Ten weeks after the spontaneous bruising had appeared the patient became pregnant again. No vaginal blood loss was noticed but bruises continued to develop during the first two months of pregnancy. No attempt was made to treat her with blood products, steroids or other immunosuppressives. During the third month all clinical evidence of a bleeding tendency disappeared, and the pregnancy progressed normally. Labour was induced at 39 weeks' gestation and the birth of the second baby was uncomplicated. Postpartum blood loss was normal and during the nine months after the birth there were no signs of bleeding in mother or baby.

\section{Methods}

Factor VIII coagulant activity (VIII:C) was measured by the two-stage technique of Biggs and Douglas (1953) and antibody to factor VIII by the method of Biggs and Bidwell (1959). Platelet counts were performed manually and the bleeding time was measured by Ivy's method. Platelet aggregation was performed on fresh platelet-rich plasma in a Born-Michal aggregometer and platelet retention by Bowie's method with glass bead columns (Bowie et al., 1969). Von Willebrand factor (VIII:WF) was assayed by the method of Weiss et al. (1973). Factor VIII related antigen (VIIIR:AG) was determined by immunoelectrophoresis (Laurell, 
1966). Platelet-bound IgG and serum anti-platelet antibody were tested by a quantitative complement lysis inhibition assay (Dixon et al., 1975) and antiplatelet agglutinins by a modification of the method of Dausset (1954).

\section{Results}

Factor VIII:C, factor VIII antibody levels, platelet counts, and bleeding times during and after the second pregnancy are shown in the Figure.

Immediately after the second baby was born the factor VIII:C level of the mother was $92 \mathrm{IU} / \mathrm{dl}$ and antibody to factor VIII was not detectable. In the postnatal period the mother's factor VIII:C fell to just below normal but antibody to factor VIII did not reappear, and the factor VIII:C returned to normal by the eighth week post partum (Figure); it was still normal five months later. The baby's factor VIII:C at birth was $37 \mathrm{IU} / \mathrm{dl}$ (cord blood) but rose to $54 \mathrm{IU} / \mathrm{dl}$ by the ninth day and was $58 \mathrm{IU} / \mathrm{dl}$ seven months later. No antibody to factor VIII was detectable, and the results of other coagulation tests remained within normal limits for her age.

Factor VIIIR:AG was $200 \%$ at 29 weeks' gestation. It remained above $200 \%$ (normal for pregnancy) throughout the last trimester and had fallen to $114 \%$ (normal $50-150 \%$ ) by seven months post partum.

Platelet aggregation with ADP, adrenaline, ristocetin, and collagen was normal in tests done from 29 weeks to term, and VIII:WF was normal at 32 weeks' gestation. However, platelet retention by glass beads (normal range $\mathbf{4 0 - 9 0 \% )}$ was very much reduced $(0 \%, 17 \%, 5 \%)$ at 32,34 , and 39 weeks.
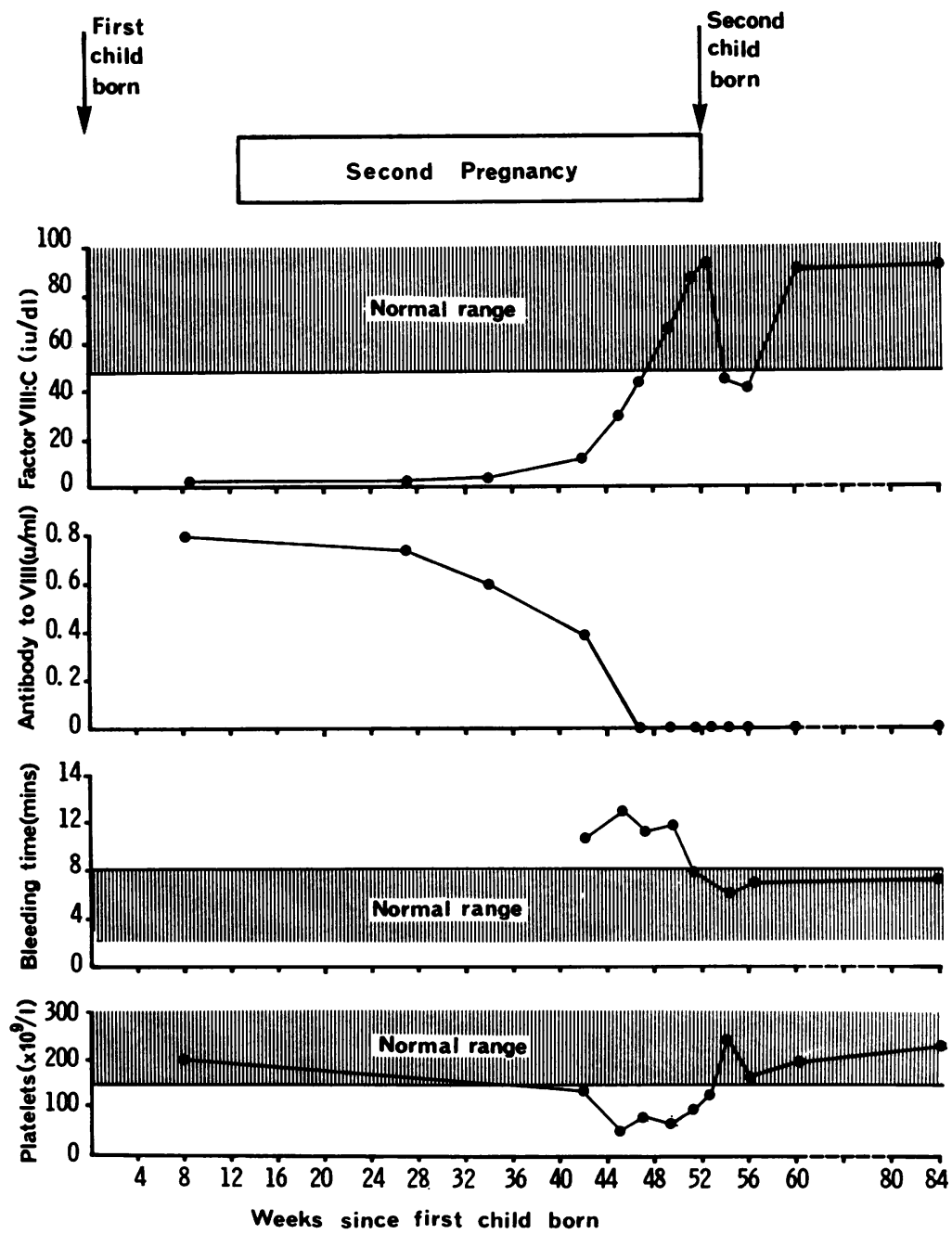

Figure Factor VIII: C and factor VIII antibody levels, bleeding times, and platelet counts during and after the second pregnancy. 
Platelet-bound IgG was normal and serum antiplatelet IgG was not detected at 34 weeks or at term. Platelet agglutinins were not present at 34 weeks.

Further investigations at the time of the coagulation abnormality failed to establish any other pathology. Haemoglobin and white cell count remained normal, blood chemistry and liver function were normal, antinuclear factor and other autoantibodies were not present.

\section{Discussion}

There have been approximately 30 case reports of postpartum coagulation defects of this type. These are listed in the Table. Nearly all the inhibitors tested were found to be directed against factor VIII. Only two were found to be anti-factor IX antibodies (Marmont et al., 1969; Özsoylu and Özer, 1973). The antibody was usually detected within a few months of the delivery and disappeared spontaneously after a variable time, ranging from four months to more than 10 years. There is only one report of a patient developing a factor VIII antibody for the first time during pregnancy rather than in the postpartum period (Marengo-Rowe et al., 1972). In most cases pregnancy and delivery were quite normal and the patients had been completely healthy. However, three patients had some evidence of an auto-immune disorder before the development of the inhibitor (Barkhan, 1952; Robboy et al., 1970).

Clinical features differ slightly from those of haemophilia in that large ecchymoses, muscle bleeds, haematuria, menorrhagia, and retroperitoneal bleeds are more common than haemarthroses and may be fatal (Table).

There are four reports of postpartum women with factor VIII inibitors in which further pregnancies are mentioned. In three of these (Hewlett and Haden, 1949; Conley et al., 1950; Margolius et al., 1961) there was some evidence of a continuing bleeding tendency during and after the subsequent pregnancy. In the fourth (Frick, 1953), the severity of the bleeding increased during the subsequent pregnancy. Conversely, our patient went into remission during her second pregnancy, indicating that pregnancy does not necessarily affect the natural progress of the disorder.

The babies born to mothers with pre-existing coagulation defects have all been clinically normal although in two cases the mothers were known to

Table Reported cases of postpartum coagulation defects due to factor VIII inhibitors§

\begin{tabular}{|c|c|c|c|c|c|}
\hline Author & & $\begin{array}{l}\text { Age of } \\
\text { patient } \\
\text { (years) }\end{array}$ & $\begin{array}{l}\text { Number of } \\
\text { pregnancies } \\
\text { prior to } \\
\text { symptoms }\end{array}$ & $\begin{array}{l}\text { Time since } \\
\text { last delivery } \\
\text { at onset of } \\
\text { symptoms }\end{array}$ & Outcome \\
\hline Rosenthal et al. $\dagger$ & 1937 & 28 & Not stated & 3 years & Complete recovery after 13 years \\
\hline Madison and Quick & 1945 & 29 & 3 & 17 months & Died (respiratory obstruction due to haemorrhage) \\
\hline $\begin{array}{l}\text { Chargaff and West } \ddagger \\
\text { Fantl and Nance }\end{array}$ & $\left.\begin{array}{l}1946 \\
1946\end{array}\right\}$ & 30 & 1 & 4 months & Complete recovery after 11 years \\
\hline $\begin{array}{l}\text { Fantl and Nance } \\
\text { Heinle } \text { et al. }\end{array}$ & 1946\{ & & & & Clinical recovery after 6 years \\
\hline Hewlett and Haden & $1949\}$ & 33 & 1 & 12 months & Laboratory tests normal after 10 years \\
\hline Hewlett and Haden & 1949 & 40 & $5+1 *$ & 3 months & Complete recovery within 2 years \\
\hline Dreskin and Rosenthal & 1950 & 30 & 1 & 4 months & Clinical recovery after 13 months \\
\hline Conley et al. $\ddagger$ & 1950 & 30 & $1+3 *$ & Immediate & Continued for at least 7 years \\
\hline Barkhan & 1952 & 26 & $0+3 *$ & Not stated & Not stated \\
\hline Biggs and Macfarlane & 1953 & 35 & 2 & 8 months & Continued for at least 6 months \\
\hline Frick & 1953 & 24 & 1 & 3 months & Complete recovery after $2 \frac{1}{2}$ years \\
\hline O'Brien & 1954 & 35 & 1 & 3 months & Complete recovery after 4 months \\
\hline Bruno and Brody & 1954 & 27 & 1 & 3 months & Not stated \\
\hline Torregrosa et al. & 1954 & 36 & 1 & 3 weeks & Died (retroperitoneal haemorrhage) \\
\hline Alexander & 1955 & 21 & 1 & 12 days & Died (uncontrollable postpartum haemorrhage) \\
\hline Nilsson et al. & 1958 & 32 & 1 & 4 months & Complete recovery after 1 year \\
\hline Margolius et al. & 1961 & 30 & 7 & 3 months & Complete recovery within 6 years \\
\hline Margolius et al. & 1961 & 24 & 1 & 2 months & Clinical recovery after 8 months \\
\hline Bloom et al. & 1966 & 29 & 1 & 3 months & Complete recovery after 19 months \\
\hline Greenwood and Rabin & 1967 & 20 & 1 & 6 days & Clinical recovery within 3 months \\
\hline Shapiro & 1967 & 36 & 3 & 2 months & Complete recovery after 6 months \\
\hline Sherman et al. & 1969 & 22 & Not stated & 1 week & Complete recovery within 4 months \\
\hline Robboy et al. & 1970 & 23 & & 2 months & Complete recovery within 18 months \\
\hline Robboy et al. & 1970 & 21 & Not stated & 2 months & Clinical recovery within 4 weeks \\
\hline $\begin{array}{l}\text { Marengo-Rowe et al. } \\
\text { Fox and Tilson }\end{array}$ & $\left.\begin{array}{c}1972 \\
1974\end{array}\right\}$ & 14 & 1 & In pregnancy & Complete recovery within 1 year \\
\hline
\end{tabular}

*Abortions †Outcome reported by Dreskin and Rosenthal (1950) ‡These two papers report the same patient

$\$$ In a few of the early reports an inhibitor was not demonstrated although the clinical and laboratory features were highly suggestive of this type of coagulation defect. 
have detectable inhibitor and a clinical bleeding tendency at the time of birth (Frick, 1953; MarengoRowe et al., 1972). The unusual case described by Frick is the only one in which the baby, though clinically normal, was born with a coagulation inhibitor corresponding exactly to that of the mother. The anticoagulant was detectable in the baby for about two and a half months. Assuming that these inhibitors are IgG antibodies, they are likely to cross the placenta and persist for several weeks in the neonate, as do anti-Rhesus or anti-viral antibodies. Although the patient described by Marengo-Rowe et al. had detectable factor VIII antibody at the time of birth, there was no evidence that this antibody had crossed the placenta. The baby was born prematurely with a normal level of factor VIII $(80 \%)$ although the mother's level was very low ( $3 \%$ of normal).

In our case the baby's factor VIII was low but there was no bleeding tendency and no detectable antibody to factor VIII.

The thrombocytopenia, long bleeding time, and abnormal platelet retention in our patient were first noted in the last trimester after the titre of antibody to factor VIII had fallen and factor VIII:C was rising. They had all returned to normal by four weeks post partum. Platelet function tests were not performed earlier in the pregnancy.

Our patient had no evidence of an auto-immune disorder and, in particular, no detectable serum anti-platelet IgG or abnormal platelet surface IgG even when her platelet count was low and the platelet function abnormal. Acquired von Willebrand's disease was excluded by high VIIIR:AG, normal platelet aggregation with ristocetin, and normal VIII:WF.

The aetiology of this disorder is unknown. It is thought that the pregnant mother can be sensitised to soluble fetal plasma proteins such as the lipoprotein allotypes (Dürwald et al., 1965) but there is, at present, no definite experimental evidence that factor VIII antigenic allotypes exist. If the maternal immune system is stimulated by fetal factor VIII the antibody so formed must crossreact with maternal factor VIII if the bleeding tendency is to be explained. One would expect such an antibody to reappear after some of the subsequent pregnancies, as in Rhesus sensitisation, but relapses have not been reported. The variable nature of this disorder also argues in favour of a more complex pathogenesis.

There is not only an association between factor VIII antibodies and auto-immune disorders, such as rheumatoid arthritis and systemic lupus, but also a well-known alteration of immune reactivity in normal pregnancy. These two observations suggest that a likely explanation of postpartum factor VIII antibodies is that of a temporary breakdown in the mother's tolerance to her own factor VIII. Whether or not this is the case, this rare disorder does resemble other auto-immune states in its variable onset and duration, its varying severity, and in the fact that its aetiology is still a mystery.

We are indebted to Mr David Morris, of Queen Charlotte's Maternity Hospital, and Dr Helen Dodsworth, of St. Mary's Hospital, London, for referring the patient to us and for permission to publish the case; to Dr Katharine Dormandy for valuable help and encouragement; and to the technicians of the Haemophilia Centre, Royal Free Hospital, for expert technical assistance.

This work was supported in part by a grant from the Ernest Kleinwort Trust, which is gratefully acknowledged.

\section{References}

Alexander, B. (1955). Coagulation, haemorrhage and thrombosis. New England Journal of Medicine, 252, 484-494.

Barkhan, P. (1952). Observations on a coagulation defect characterized by thrombocytopenia with a circulating anticoagulant. South African Journal of Medical Science, 17, 87-99.

Biggs, R., and Bidwell, E. (1959). A method for the study of antihaemophilic globulin inhibitors with reference to six cases. British Journal of Haematology, 5, 379-395.

Biggs, R., and Douglas, A. S. (1953). The thromboplastin generation test. Journal of Clinical Pathology, 6, 23-29.

Biggs, R., and Macfarlane, R. G. (1953). Human Blood Coagulation and its Disorders. Oxford University Press, London.

Bloom, A. L., Davies, A. J., and Rees, J. K. (1966). A clinical and laboratory study of a patient with an unusual factor VIII inhibitor. Thrombosis et Diathesis Haemorrhagica, 15, 12-28.

Bowie, E. J. W., Owen, C. A., Jr., Thompson, J. H., and Didisheim, P. (1969). Platelet adhesiveness in von Willebrand's disease. American Journal of Clinical Pathology, 52, 69-77.

Bruno, M. S., and Brody, H. S. (1954). Hypothromboplastinemia associated with a circulating anticoagulant and hemorrhagic diathesis. American Journal of Medicine, 16, 756-763.

Chargaff, E., and West, R. (1946). The biological significance of the thromboplastic protein of blood. Journal of Biological Chemistry, 166, 189-197.

Conley, C. L., Ratnoff, O. D., Ellicott, C. E., and Hartmann, R. C. (1950). Studies on the initiation of blood coagulation. II. An anticoagulant inhibiting the activation of a plasma thromboplastic factor. Journal of Clinical Investigation, 29, 1182-1188.

Dausset, J. (1954). Normal and pathological platelet agglutinins investigated by means of the shaking 
method: confirmation of the presence of $A$ and $B$ antigens in platelets. Vox Sang, 4, 204-213.

Dixon, R., Rosse, W., and Ebbert, L. (1975). Quantitative determination of antibody in idiopathic thrombocytopenic purpura. New England Journal of Medicine, 292, 230-236.

Dreskin, O. H., and Rosenthal, N. (1950). A hemophilialike disease with prolonged coagulation time and a circulating anticoagulant. Report of a case in a female. Blood, 5, 46-60.

Dürwald, W., Leopold, D., and Krämer, K-H. (1965). The formation of precipitating antibodies after multiple pregnancies. Vox Sang, 10, 94-100.

Fantl, P., and Nance, M. H. (1946). An acquired haemorrhagic disease in a female due to an inhibitor of blood coagulation. Medical Journal of Australia, 2, 125-128.

Fox, G. L., and Tilson, H. B. (1974). Acquired hemophilia due to a circulating anticoagulant. Journal of Oral Surgery, 32, 27-30.

Frick, P. G. (1953). Hemophilia-like disease following pregnancy, with transplacental transfer of an acquired circulating anticoagulant. Blood, 8, 598-608.

Greenwood, R. J., and Rabin, S. C. (1967). Hemophilialike postpartum bleeding. Obstetrics and Gynecology, 30, 362-366.

Heinle, R. W., Weisberger, A. S., Vignos, P. J., and Holden, W. B. (1949). Hemorrhagic diathesis associated with low thromboplastic activity and a circulating anticoagulant (abstract). Journal of Laboratory and Clinical Medicine, 34, 1606-1607.

Hewlett, J. S., and Haden, R. L. (1949). Hemophilialike disease in women. Journal of Laboratory and Clinical Medicine, 34, 151-157.

Laurell, C. B. (1966). Quantitative estimation of proteins by electrophoresis in agarose gel containing antibodies. Analytical Biochemistry, 15, 45-52.

Leitner, A., Bidwell, E., and Dike, G. W. R. (1963). An antihaemophilic globulin (factor VIII) inhibitor: purification, characterization and reaction kinetics. British Journal of Haematology, 9, 245-258.

Madison, F. W., and Quick, A. J. (1945). Hemophilialike disease in the female. American Journal of Medical Science, 209, 443-447.

Marengo-Rowe, A. J., Murff, G., Leveson, J. E., and Cooke, J. (1972). Hemophilia-like disease associated with pregnancy. Obstetrics and Gynecology, 40, 56-64.

Margolius, A., Jr., Jackson, D. P., and Ratnoff, O. D. (1961). Circulating anticoagulants: a study of 40 cases and a review of the literature. Medicine (Baltimore), 40, 145-202.

Marmont, A., Bertorello, C. F., Damasio, E., and Rossi, F. (1969). Autoimmunocoagulopatia da anticorpo anti-fattore IX (PTC). Folia Allergologica (Roma), 16, $13-48$.

Nilsson, I. M., Skanse, B., and Gydell, K. (1958), Circulating anticoagulant after pregnancy and its response to ACTH. Acta Haematologica, 19, 40-50.

O'Brien, J. R. (1954). An acquired coagulation defect in a woman. Journal of Clinical Pathology, 7, 22-25.

Özsoylu, S., and Özer, F. L. (1973). Acquired factor IX deficiency. Acta Haematologica, 50, 305-314.

Robboy, S. J., Lewis, E. J., Schur, P. H., and Colman R. W. (1970). Circulating anticoagulants to factor VIII: immunochemical studies and clinical response to factor VIII concentrates. American Journal of $\overrightarrow{0}$ Medicine, 49, 742-752.

Rosenthal, N., Vogel, P., and Beres, D. (1937). Acquired o haemophilia in a female. In Anniversary Volume for $\underset{\mathbb{D}}{ }$ Robert Tilden Frank; by his colleagues, collaborators, associates and friends [S. H. Geist et al.]. C. V. Mosby, St. Louis.

Shapiro, S. S. (1967). The immunologic character of acquired inhibitors of antihaemophilic globulin (factor VIII) and the kinetics of their interaction with factor VIII. Journal of Clinical Investigation, 46, 147-156.

Sherman, L. A., Goldstein, M. A., and Sise, H. S.

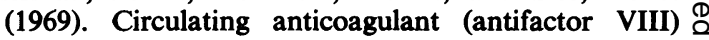
treated with immunosuppressive drugs. Thrombosis et Diathesis Haemorrhagica, 21, 249-258.

Torregrosa, M. V., Ramos-Morales, F., Pons, E., Jr., Andino, A. M. de., Jr., and Rivera, R. S. D. (1954). Circulating antithromboplastic anticoagulant: ineffectiveness of cortisone and corticotrophin. American Journal of Medical Science, 228, 269-274.

Weiss, H. J., Hoyer, L. W., Rickles, F. R., Varma, A., and Rogers, J. (1973). Quantitative assay of a plasma factor deficient in von Willebrand's disease that is necessary for platelet aggregation. Journal of Clinical Investigation, 52, 2708-2716. 